\title{
USE OF ALLOPLASTIC MESHES IN ABDOMINAL WOUNDS OF RATS WITH INDUCED PERITONITIS
}

\author{
Uso de telas inorgânicas em feridas abdominais de ratos com peritonite induzida \\ Rafael Calvão BARBUTO, Ivana DUVAL-ARAUJO, Sumara Marques BARRAL, Raphael Grossi ROCHA, \\ Cristiane de Souza BECHARA, Alfredo José Afonso BARBOSA
}

From the Programa de Pós-Graduação em Cirurgia, Faculdade de Medicina, Universidade Federal de Minas Gerais, Belo Horizonte, MG, Brasil (Post-Graduate Program in Surgery, Faculty of Medicine, Federal University of Minas Gerais, Belo Horizonte, MG, Brazil)

HEADINGS - Wound healing. Peritonitis. Hernia. Surgical mesh. Abdominal wall.
ABSTRACT - Background: The use of alloplastic meshes has been historically contra-indicated in patients with infection. Aim: To evaluate the use of polypropylene meshes in the treatment of abdominal wall defects in rats with peritonitis. Methods: Twenty Wistar female rats were divided into two groups: induction of peritonitis (test group) and without peritonitis (control group). An abdominal wall defect was created in all animals, and polypropylene mesh was applied. The evaluation of the tensile strength of the mesh was carried out using tensiometer and microscopic analysis of the healing area was done. Results: More adhesion of the mesh to the rat abdominal wall was observed in test group. The histopathological analyses showed prevalence of moderate to accentuated granulation tissue in both groups, without significant differences. Conclusion: The use of the mesh coverage on abdominal wall defects of rats with induced peritonitis did not show worse results than its use in healthy animals, nor was its integration to the resident tissue any worse.

\section{Correspondence}

Ivana Duval Araujo

E-mail: idaraujo@medicina.ufmg.br.

Financial source: none

Conflicts of interest: none

Received for publication: 13/09/2013

Accepted for publication: 12/12/2013

DESCRTORES - Cicatrização. Peritonite. Hérnia. Tela cirúrgica. Parede abdominal.
RESUMO - Racional: O uso de telas inorgânicas historicamente é contra-indicado em paciente com infecções. Objetivo: Avaliar o comportamento e cicatrização de paredes abdominais com uso de telas de polipropileno após infecções intracavitárias. Método: Foram estudadas 20 ratas Wistar aleatoriamente divididas nos grupos Estudo (com peritonite) e Controle (sem peritonite). Um defeito na parede abdominal foi criado em todos os animais, onde foi aplicada tela de polipropileno. Foi feita avaliação da força de tensão com uso de tensiômetro, além de análise histológica da área cicatricial. Resultados: Observou-se maior adesividade da tela às paredes dos animais do grupo Estudo quando comparado ao grupo Controle. A análise histopatológica mostrou prevalência de tecido de granulação de acentuado à moderado em ambos os grupos, sem diferença significativa. Conclusão: O uso de telas inorgânicas nos defeitos da parede abdominal em ratos com peritonite induzida não mostrou resultado pior do que aquele obtido de animais sem infecção, tanto em relação à sua integração quanto ao tecido cicatricial no defeito da parede abdominal.

\section{INTRODUCTION}

$\mathrm{T}$ he treatment of abdominal wall hernias with synthetic meshes was first described by Usher in the 1950s and heralded a new era of surgical history ${ }^{18}$. The characteristics of these meshes present the advantages observed in biomaterials, such as inertia in the presence of infection and the ability to maintain tensile strength. Alloplastic meshes have gained more acceptance since the development of biocompatible materials, not only because the technique is practicable, but mainly as a result of the reduction in recurrence rates ${ }^{11,17}$. 
The use of polypropylene meshes in emergency surgeries and contaminated procedures has been discussed for almost 40 years, without a definite conclusion ${ }^{11,18}$. However, in many abdominal procedures, contaminated ones and even infected ones, the means to perform an effective laparorraphy are required. Some clinical situations, such as patients with perforated digestive tract tumors and peritonitis, the elderly, critically ill and severely injured patients that require to be operated on the abdomen, would benefit from primary repair rather than being submitted to another operation.

No reports that specifically address complications of mesh repair in infected and contaminated surgeries have been published. This study aims to obtain experimental data that evaluates the use of mesh repair in contaminated tissues.

\section{METHODS}

This experiment was kept according ethical principles of experimental research, and was approved by Ethical Committee of Animal Experimental Studies of Universidade Federal de Minas Gerais under Protocol Number 143/2007. Twenty Wistar female rats with weight ranged from 250 to $310 \mathrm{~g}$ were distributed into two experimental group: 1) test group: induction of peritonitis, creation of abdominal wall defect, mesh repair and evaluation of tensile strength after seven days; 2) control group: absence of peritonitis, creation of abdominal wall defect, mesh repair and evaluation of tensile strength after seven days.

The animals were anesthetized with an intramuscular injection of $60 \mathrm{mg} / \mathrm{kg}$ of Cetamin (Ketaminâ - Cristália, São Paulo, Brasil) associated to $10 \mathrm{mg} / \mathrm{kg}$ of $2 \%$ Xilazine (Calmiun - União Química, São Paulo, Brasil). All surgical procedures were carried out with instruments sterilized by chemical methods.

\section{Induction of peritonitis}

The method used was cecal ligation and puncture. After assepsy with povidine-iodine, there was made a cecal pouch using a 4.0 silk, followed by section of the colonic wall with surgical scissors for $0.1 \mathrm{~cm}$, and them the abdomen was closed with continuous 2-0 nylon suture in one layer. In group B, only laparotomy and manipulation of the bowel was performed, followed by closure of the abdominal wall with continuous 2.0 nylon suture.

After $2 \mathrm{~h}$, the abdomen was reopened, cleaning with saline lavage and antimibrobial (ceftriaxone 30 $\mathrm{mg} / \mathrm{kg}$ ) administred by intramuscular injection.

All of the animals were kept under observation for $4 \mathrm{~h}$, in separate cages, and fed with glucose solution at $25 \%$ and water.

After $4 \mathrm{~h}$ the abdomen of all of the animals was reopened and cavity washed with saline solution at $38^{\circ} \mathrm{C}$. This was done three times with a syringe of $20 \mathrm{ml}$, under pressure (using a $25 \times 7 \mathrm{~mm}$ needle), the excess of the saline solution was aspirated and the necrotic part of the cecum removed. All animals received an intra-muscular dose of ceftriaxone during the second anesthetic procedure and $12 \mathrm{~h}$ later.

\section{Creation of the abdominal wall defect}

A flap of abdominal wall with $1 \mathrm{~cm}$ of diameter was removed, including the muscular and aponeurotic layers. A patch of omentum was used to protect the bowel and abdominal wall defect was treated with the use of a polypropylene mesh (MarlexTM, CR BARD, Salt Lake City, UT), of 4,2 x 2,7 $\mathrm{cm}$ fixed intra-peritoneally, on the rectus abdominis borders with simple interrupted sutures of catgut 4,0 (Dexon - Davis Gerck American Cyanamit Company, Pearl River, NY). All of the animals were treated with analgesics during the postoperative period (Tenoxican 0,3 $\mathrm{mg} / \mathrm{kg}$ ) and animals observed during seven days.

\section{Mesh detachment tension (MDT)}

The tension necessary to detach the mesh from the rats abdominal wall was measured in Newtons (N) with the same tensiometer. Seven days after the mesh implantation, the animals were sacrificed with anesthetic overdose and put in the tensiometer (Figure 1). The skin was softly separated from the mesh, and a hook attached to the central point of the prosthesis. This hook was linked to a thread that was connected to a motor and the system of force measurement, and the MDT evaluated by applying a progressive force to the mesh. It was not possible to eliminate friction force from each procedure, but it was similar in all the animals. When the mesh detach from the tissue, there was computed the value in Newton (N).

\section{Histological evaluation}

After the detachment, a sample of abdominal wall including the border of abdominal wall defect with the mesh was removed and fixed in formalin solution at $10 \%$, processed by routine histological preparation, and obtained sections of $0,4 \mu$ that were stained by H\&E. The histopathological parameters studied were inflammatory reaction, predominant cell type in inflammatory infiltrate, granulation tissue, giant cell reactions, fibrosis and necrosis.

MDT data was analyzed with the Kruskall-Wallis test, and considered difference to $p$ value less than 0.05 . The histological parameters were compared by means Chi-square test with Fisher-Correction, and considered difference to $p$ value less than 0.05 . 
RESULTS

The median weight of animals was $286.0 \mathrm{~g}$ ( $259.0 \mathrm{~g}$ to $308.0 \mathrm{~g}$ ) for test group and $272.5 \mathrm{~g} \mathrm{(259.0}$ $\mathrm{g}$ to $310.0 \mathrm{~g}$ ) for control group, with no significant differences $(p=0.28)$.

Suture dehiscence was observed in 11 animals, five in rats with peritonitis (test group) and six in control group. There was no significant differences $(p=0.58)$. The epithelization also was not different between the two groups $(p=1.0)$.

The median value of MDT in peritonitis rats (test group) was $62 \mathrm{~N}(45-65 \mathrm{~N})$, and in control groups (without peritonitis) was $50 \mathrm{~N}(40-62 \mathrm{~N})$, with more elevated value in peritonitis rats $(p=0.02)$.

The histopathologic analyses showed the prevalence of moderate to accentuate granulation tissue associated with the two groups. It was observed that the granulation was moderate in $40 \%$ and accentuated in $40 \%$ of the animals from control group, and moderate in $30 \%$ and accentuated in $50 \%$ of test group. The inflammatory response was moderate in $60 \%$ of the animals in each group. As regards inflammatory infiltration, it was predominantly mononuclear in $50 \%$ of the specimens of the control group and polimorphonuclear in the remainder, whereas it was mononuclear in $60 \%$ of the samples from test group (polimorphonuclear in $40 \%)$, without statistical difference $(p=0.59)$. Giant cell reactions were observed in $30 \%$ of the specimens from test group and in $60 \%$ of the samples from control group. Early-stage fibrosis was seen in $80 \%$ of control group samples and in $90 \%$ of test group, without statistical significance $(p=0.17)$.

\section{DISCUSSION}

There are some discussions about the use of synthetic materials in infected surgical procedures, but no definitive conclusions have been reached. In fact, research on the use of alloplastic implants in unsterile environment is infrequent and it does not shed light on the most important point of the problem: is the use of synthetic meshes contraindicated in cases of infection? Historically, the use of polypropylene meshes is described in cases of temporary closure in infected abdomen, but there is little and poor information about its definitive application in this situation ${ }^{4,12}$. Schnitt and Grinnan treated injured soldiers with infected abdomen using MarlexÒ mesh coverage and reported good results ${ }^{12}$. During the 70s, reported the satisfactory evolution of a patient with muscle necrosis, in which the abdominal wall defect was treated with an alloplastic mesh.

Also, patients with peritonitis and multiple organ insufficiency were treated with the use of these meshes inserted onto the abdominal wall with a good prognosis ${ }^{6}$. On the other hand, according to other reports, there were good immediate results, but a number of long-term complications, such as chronic infections and skin erosion 5,16,17,19. Besides, Voyle and cols have observed that $50 \%$ to $90 \%$ of the cases reported in the literature were unsuccessful, and it was necessary to remove the mesh ${ }^{19}$. As its the removal is not without risks - sometimes leading to bleeding, fistulas, hernias and recurrence of the infection-, historically most of the authors have been reluctant to accept its use in cases of infections or contamination $3,6,9,10,17$.

On the other hand, Birolini et al. were successful in a retrospective trial of 20 patients with complications. They concluded that the application of synthetic materials did not have to be avoided in cases of abdominal infection, when classical principles of surgery, such as antisepsis and hemostasia, were respected ${ }^{14}$.

The tension strength of scars may be affected by different factors such as diabetes mellitus, corticosteroids, immunosuppressive drugs, malnutrition, autoimmune diseases and even uremia. Others factors such bacterial colonization, foreign-body reaction, low blood flow associated with tissue hipoxia, high suture tension and the use of synthetic implants are also associated with decrease in healing. The biological healing in response to alloplastic material has been widely studied, but further questions are emerging in this context, which suggests that this is a challenging issue $2,3,7,10$. The initial migration of inflammatory cells is gradually replaced by a different panel scene, in which fibroblasts and giant cells are dominant. These alterations markedly increase the adhesion of the prosthesis to the resident tissues, which is observed during the early months.

According observed in another study ${ }^{2}$, the present study showed that there was greater adhesion of the MarlexOे mesh coverage in the group of animals submitted to a peritoneal infection. This fact could be explained by a more profuse inflammatory response and the presence of a greater number of polymorphonuclear cells. Although this data was relevant, there is a need for other experimental studies, to confirm the behavior of alloplastic materials applied to infected tissues, especially in reconstructive surgical procedures.

\section{CONCLUSION}

The use of Marlex mesh coverage onto abdominal defects produced in rats with induced acute peritonitis did not show worse results than its use in healthy animals, nor was its integration to the resident tissue any worse during the early seven days. 


\section{REFERENCES}

1. Birolini C, Utiyama EM, Rodrigues AJ Jr, Birolini D. Elective colonic operation and prosthetic repair of incisional hernia: does contamination contraindicate abdominal wall prosthesis use? J Am Coll Surg 2000; 191: 366-72.

2. Cerise EJ, Busuttil RW, Craighead CC, Ogden WW. The use of mersilene mesh in repair of abdominal wall hernias: a clinical and experimental study. Ann Surg 1975; 181: 728-34.

3. Corcione $F$, Cristinzio $G$, Maresca $M$, et al. Primary inguinal hernia: the held-in mesh repair. Hernia 1997; 1: 37-40.

4. D' Acampora AJ, Lopes A, Ludwig FC, Lima AG. Peritoneostomia no tratamento da peritonite difusa: análise de onze casos. ACM arq catarin méd 1989; 18(1): 15-19.

5. Dayton MT, Buchele BA, Shirazi SS, Hunt LB. Use of absorbable mesh to repair contaminated abdominal-wall defects. Arch Surg 1986; 121: 954-60.

6. Dibello JN Jr, Moore JH Jr. Sliding myofascial flap of the rectus abdominus muscles for the closure of recurrent ventral hernias. Plast Reconstr Surg 1996; 98: 464-69.

7. Ferrando JM, Vidal J, Armengol M, Gil J, Manero JM, Huguet $P$, Segarra A, Quiles MT, Schwartz S, Via MAA. Experimental evaluation of a new layered prosthesis exhibiting a low tensile modulus of elasticity: long-term integration response within the rat abdominal wall. World J Surg 2002; 26: 409-15.

8. Ferraz ED, Vieira $O M$ Técnica de fechamento progressivo na laparostomia e descompressão abdominal. Rev Col Bras Cir 2000. 27(4):237-244.

9. Geisler DJ, Reilly JC, Vaughan SG, Glennon EJ, Kondylis PD. Safety and outcome of use of nonabsorbable mesh repair of fascial defects in the presence of open bowel. Dis Colon Rectum 2003; 46: $1118-23$
10. Kelly ME, Behrman SW. The safety and efficacy of prosthetic hernia repair in clean-contaminated wounds. Am Surg 2002; 68: 528-29.

11. Parker SJ, Watkins PE. Experimental models of Gram-negative sepsis. Br J Surg 2001; 88: 22-30.

12. Schmitt JH Jr, Grinnan GLB: Use of Marlex mesh in infected abdominal war wound. Am J Sur 1967; 113: 825-828.

13. Schein M, Geceltes G, Freinkel W, et al. Peritoneal lavage in abdominal sepsis: a controlled clinical study. Arch Surg 1990; 125: 1132-35.

14. Simão TS, Rocha FS, Moscon FB, Pinheiro RR, Barbosa FEAS, Faiwichow $L$ Vacuum dressing technique to temporary cover of laparostomy. ABCD arq Bras Cir Dig 2013. 26(2):147-150

15. Sebben GA, Rocha SL, Von Bahten LC, Biondo-Simões MLP, Ramos FHA, Pilonetto M, Zonatto LM Infection on the meshes implantation área in the abdominal wall of rats with induced bacterial peritonitis. Acta Cir Bras 2006. 21(3):155-160.

16. Stone HH, Fabian TC, Turkleson ML, Jurkiewicz MJ. Management of acute full-thickness losses of the abdominal wall. Ann Surg 1981; 193: 612-17.

17. Temudom T, Siadati M, Sarr MG. Repair of complex giant or recurrent ventral hernias by using tension-free intraparietal prosthetic mesh (Stoppa technique): Lessons learned from our initial experience (fifty patients). Surgery 1996; 120:738-44.

18. Usher FC, Wallace AS. Tissue reaction to plastics. A comparison of Nylon, Orlon, Dacron, Teflon and Marlex. Arch Surg 1959; 76: 997-99.

19. Voyles CR, Richardson JD, Bland KI, et al. Emergency abdominal wall reconstruction with polypropylene mesh. Ann Surg 1981; 194: 219-23. 